\title{
HIV/AIDS in Cameroon: Rising gender issues in policy-making matters
}

\author{
Jude Awuba and Gloria Macassa \\ Department of Public Health Sciences, Division of Social Medicine, Karolinska Institutet, SE 17176 Stockholm, \\ Sweden
}

\section{SUMMARY}

This literature review investigated gender differentials in HIV/AIDS in Cameroon and to which extent gender was taken into account in the country's current policy on HIV/AIDS. The review found that in Cameroon women were at increased risk of being infected with HIV/AIDS compared to men and that apart from biological vulnerability, socio-cultural as well as economic factors accounted for those differences. In addition, the review found that at the policy level, the government has drawn up plans to reduce the high prevalence of HIV/AIDS among women. However, although the current policy acknowledged the need for tackling gender differentials in HIV/AIDS transmission; little has been done at the level of implementation. The current policy needs to be implemented in a more effective manner and a multisectorial approach should be explored in order to curb the current trend of the feminization of HIV/AIDS in Cameroon.

[Afr J Health Sci. 2007; 14:118-128]

\section{Introduction}

AIDS has killed more than 25 million people since it was first recognized in 1981, making it one of the most destructive epidemics in recorded history [1]. The total number of people living with HIV/AIDS reached its highest level: an estimated 40.3 million people are now living with the disease [2]. The overwhelming majority of people with HIV, some $95 \%$ of the global total, live in the developing world [3] and sub- Saharan Africa (SSA) is the epicentre, with just over $10 \%$ of the world's population; it is home to over $60 \%$ of all people living with HIV [4]. Among young people infected with HIV in this region, around three in four are female [4]. The contrast in the prevalence and impact of HIV/AIDS between high-income countries and middle and low-income countries on the other hand, is striking [5]. While HIV prevalence and AIDS-related mortality is declining in the United States, Western Europe and Australia, it continues to rise rapidly in SSA, Southeast Asia, and Latin America [2]. For example, a combined frequency of risky behaviour and high frequency of sexually transmitted diseases (STDs) acts synergistically to further propel the epidemic in many areas of the low and middle income countries largely due to poverty, illiteracy and socio-cultural practices [6]. The objective of this review was to investigate gender differentials in HIV/AIDS in Cameroon and to assess to which extent gender is taken into account in the country's policy making. Furthermore risk factors related to HIV/AIDS transmission among women in Cameroon are assessed.

\section{The Feminization of HIV/AIDS in sub-Saharan Africa}

The United Nations General Assembly Special Session on HIV/AIDS in 2003/2004 declared that "women and girls are disproportionately affected by HIV/AIDS" and committed UN member states to a program of action designed to reduce the impact of HIV/AIDS on women and girls, and promote and protect their human rights [7]. Over the last few years prevalence among women has accelerated from consisting of $41 \%$ of infected adults in 1997 to $50 \%$ in $2002.77 \%$ of all infected women are from SSA [4]. Nowhere is the epidemic's 'feminization' more apparent than in SSA [5]. For biological reasons, women have always been more susceptible for contracting the HIV virus than men. Biological factors include: the higher viral concentration in semen compared to vaginal fluids, larger exposed surface and longer viral contact among women [5]. However, these grounds alone cannot explain the sudden acceleration and the geographical concentration of the feminization of the epidemic in SSA, which indicates that we must look beyond the immediate circumstance of biological vulnerability to the broader socio-cultural context $[5,7]$.

There are three critical factors all interconnected that place gender issues at the core of the HIV/AIDS pandemic in SSA. These are: firstly, the risk factors and vulnerability which are substantially different for men and for women, secondly, impact of HIV/AIDS differs along gender line, and lastly, tackling the AIDS pandemic is fundamentally about behaviour change which essentially means effecting a "transformation" of gender roles and relations in SSA [8]. Women's vulnerability to HIV/AIDS is rooted in sexual, 
social, and economic inequality based on gender; however, gender inequality is further fragmented by a combination of factors such as race, class, urban/rural location, sexual orientation, religion, and culture. Understanding the context of differing vulnerability of specific groups of women and the intricate and interdependent nature of inequality is crucial, not only for identifying the complex causes of women's vulnerability, but also for finding effective solutions that address the many causes and manifestations of this inequality [9].

There is a growing global understanding that HIV/AIDS is sustained not only by biological factors but also by the social organization that supports it [10]. HIV/AIDS is most prevalent in parts of the world where poverty and economic inequality is extensive, where gender discrimination is pervasive, and where access to public services is unequal [11]. In SSA, transmission continues to be dominated by heterosexual sexual relations. African women are particularly vulnerable to HIV infection because sexual relations with men is an important means to achieve social and economic status, and for some women necessary for survival [11]. Although sexuality is distinct from gender it is intimately linked to it. It is the social construction of a biological drive [12]. An individual's sexuality is defined by whom one has sex with, in what ways, why, under what circumstances and with what outcomes [12]. The patriarchal nature of African societies continues to shape women's sexual behaviour in the region [9]. There is a culture of silence that surrounds sex which dictates that "good" women are expected to be ignorant and passive in decision- making or suggestions relating to their role in sexual activity [12]. This makes it difficult for women to be proactive in negotiating safer sex. African women still live in a world where they are expected to be submissive to men and where it is unacceptable for a woman to say no to unwanted and unprotected sex [13]. Social norms in many SSA contexts permit (and even encourage) men to engage in sex with multiple partners, favour sex with younger partners, and dominate sexual decision making [12]. Often young girls endure sexual coercion and abuse.

In Africa, marriage is a social obligation and a woman's status in society is judged based on it [14]. But the marriage of a woman generally confers to her husband the right to have her body [14]. Indeed, sex is considered a marital duty to which no woman should withdraw herself from the moment when her husband wishes it even when she has doubts about her husband's sexual life [15]. Against the backdrop of such expectations, women often feel powerless to protect themselves against HIV infection and unintended pregnancies.

Economic realities enable men to monopolize the sources of income. Women's increasing dependence on men's economic support throughout most part of the region over the last century has meant that women's personal resources, including their sexuality, have new found economic potential [16]. However, such traditional pattern holds little currency today where sexual activity can lead to HIV infection and disastrous consequences for a woman and her children [17]. Given that women clearly require all the protection, the neglect of women's sexuality arising from historically powerful patterns of gender discrimination (political, economic and cultural forces), must be viewed as stumbling blocks to efforts aimed at reversing the feminization of HIV/AIDS in SSA [18].

\section{HIV/AIDS in Cameroon}

Cameroon is located on the West Coast of Africa in the Gulf of Guinea [19]. It is often referred to as "Africa in Miniature" [20] because of its complex cultural, social and geographical diversity. Cameroon's population is estimated at slightly above 15 million, comprising some 250 ethnic groups, making her a "racial crossroads" in Africa. It is the only country in Africa with English and French as its official languages [19]. Administratively, Cameroon is divided into ten provinces. There are three religions namely: Christian, Muslim and traditional beliefs [21]

Endowed with significant petroleum and forestry resources and a rich agricultural base, Cameroon has the potential to be one of the wealthiest countries in SSA. According to the United Nations Development Report of 2003, it is grouped among countries of low human development index with an index of 0.497 [22]. Cameroon has undergone continuous political, economic and social turmoil and change since the implementation of the Structural Adjustment Program (SAP) in the 1980's proposed by the Bretton Woods Institutions. An important reform of this policy favoured the devaluation of CFA, the local currency and a cut on the budget from the social sector for example; health and education [23]. The most significant impact of the SAP is its negative influence on access to health due to a drastic cut in social services. The interplay and dynamics of change have shaped the lives and attitudes of both rural and urban people and particularly youths and women and have, in some instances, exacerbated the adverse impact of HIV/AIDS on households [21]. In Cameroon, infectious and parasitic diseases dominate the epidemiological profile as in most SSA countries [21]. Although HIV/AIDS had been discovered in 1980, the first cases in Cameroon were diagnosed in 1985 [24]. By 1994 the registered number of full-blown cases of AIDS reached 5,375 and by 2005, 510000 were HIV/AIDS positive [25, 26]. In Cameroon, 90 percent of all cases of transmission 
are through unprotected sexual contact, while transmission through contaminated blood and from mother to child accounts for about 10 [20]. An unfortunate collateral effect of HIV/AIDS is the resurgence of infectious disease such as tuberculosis [21]. The spread of the pandemic has extended in a disquieting manner throughout all the provinces of Cameroon and in different proportions with high incidence in urban than in rural areas. General prevalence rates vary from 1.7 in the North to 8.7 in the North West, while among women it is highest in North West (11.9 percent) and South West provinces (11.0 percent) [26].

\section{Current HIV policy plan in Cameroon}

The political commitment in the fight against HIV/AIDS in Cameroon translates into the development of a national strategic plan. The first short term national AIDS plan was designed in 1987, followed by two national plans for 1988 to 1992 and 1993 to 1999 [28]. The fight against HIV/AIDS in Cameroon during the period from 1987 to 1999 had several barriers including: ignorance and indifference, leading to lack of general mobilization, insufficient coordination of programs, failure to adopt a multi-sectorial approach and limited allocation of resources for the various HIV/AIDS programs. As a result, the HIV/AIDS situation worsened considerably and the HIV prevalence rate in Cameroon increased from $0.5 \%$ in 1987 to $7.73 \%$ in 2000 [29, 30]. In response to the limitations of the two short term national AIDS plan of 1988 to 1992 and 1993 to 1999, and the growing social and economic threat of the HIV/AIDS epidemic to the population, the Prime Minister launched the Plan Strategique National de Lutte Contre le SIDA, 2000-2005 later extended to 2006 [28]. According to this plan, HIV/AIDS is the priority number one of the national health development plan and it proposes strategies and programs in 20 different areas to address the epidemic. Some examples of those activities are programs that focus on illiteracy, gender issues, human rights, substance abuse, and mother-to-child transmission of HIV/AIDS [28].

The HIV/AIDS plan for the country is to preserve the health of children, women, and men in different settings such as the home, at work, at leisure and in hospital [21]. This is to be achieved through a series of measures: minimizing the risk of contamination with HIV/AIDS among children aged five to fourteen by promoting a healthy lifestyle and the development of responsible sexual behaviour. Develop information mechanisms aimed at bringing about changes in the behaviour of the sexually active population, reduce the risk of transmission of HIV from mother to child, minimize the risk of infection through blood transfusion and develop a national mechanism for solidarity with persons living with HIV/AIDS [29].

\section{Methods}

This review is based on information collected from scientific papers, national and international policy documents as well as reports on gender and HIV/AIDS in Cameroon and SSA. Quantitative and qualitative sources were assessed.

Searches were done on electronic databases to review the literature related to the topic under study. Due to the paucity of information on Francophone SSA countries in general, and Cameroon in particular on gender and HIV/AIDS, there was no limitation made for the publication dates of the literature. Initially, a broad key word; "HIV/AIDS in Cameroon" instead of "women and HIV/AIDS in Cameroon" was used to minimize the possibility of getting limited results. This was also a useful strategy to get familiarized with the evolution of HIV/AIDS in the country. Based on this search strategy it was possible to identify risk factors related to HIV/AIDS transmission among women in Cameroon which included: feminization of poverty, violence against women, women and health seeking behaviour, Female Genital Mutilation (FGM) and age mixing. In subsequent searches, specific phrases involving the risk factors identified earlier were performed for example, "feminization of poverty and HIV/AIDS among women in Cameroon", to get a detailed account of how they accounted for HIV/AIDS transmission among women. Searches were carried out in electronic search engines and databases such as PubMed, Google scholar and Google. The Cameroon Demographic and Health Survey of 2004 (CDHS) was equally used in the study. (27)

The inclusion criteria were based on literature that dealt with gender and development as well as gender and HIV/AIDS with focus on either Cameroon or SSA. Studies included those published in English or French. Articles written in any other language other than French or English were excluded and also articles that did not deal with gender issues and HIV/AIDS.

\section{Results \\ Gender differentials in prevalence of HIV/AIDS in Cameroon}

According to the CDHS 2004, HIV prevalence among adolescents (young people aged 15-24) was $4.8 \%$ of women as opposed to $1.4 \%$ of men. In the general population the prevalence of HIV/AIDS was $6.8 \%$ and $3.9 \%$ of female and male respectively [27] In both urban and rural areas $8.4 \%$ and $4.8 \%$ of women, as compared to $4.7 \%$ and $2.8 \%$ of men were HIV/AIDS positive [27]. According to that same survey, women with no education, primary, secondary and higher education had a prevalence of $3.4 \%, 4.2 \%$ and $8.2 \%$ respectively [27]. For men, the prevalence rate is 
$2.1 \%, 4.1 \%$ and $4.2 \%$ with the educational status categorized as those of women.

\section{Risk factors for HIV/AIDS transmission among women in Cameroon Feminization of poverty}

In an analysis on fostering women's participation in development through non-governmental efforts in Cameroon, Loftman [20], explains that despite their numerical strength, women who are a major force of development in the country unfortunately do not have an equal share of the country's wealth and resources compared to their male counterpart. In the economic sector, he argues, they are mostly found in the informal sector, where they operate as small entrepreneurs (they either sell food stuff on the street, operate small bars and restaurants), even in terms of waged employment, women are mostly found in teaching and nursing professions, which are usually looked upon as extension of their caring roles. The study maintains that one of the fundamental problems of the disadvantaged in society is lack of income; credit and other support services. Women have fewer legal rights than men, and have limited access to support services, credit, and inputs. The result is a marked increase in poverty [20]. The study concludes that because women have less formal employment than men, this makes then a vulnerable social group. For those that drift into prostitution, exposure to the risk of AIDS and sexually transmissible diseases is increased [20].

Another study related to reproductive lives in Francophone Africa [31] found that one of the more visible legal barriers to resources in Africa is the patrilineal system of inheritance, which means that women often lose their homes and livelihoods on the death of their husbands. Moreover, a married woman's rights to her own property are limited throughout the course of her marriage; her husband alone manages the community property, which he can sell, abandon, or mortgage at any time and also manages his wife's personal property, and exercises all rights to it [31]. Under most customs, the study indicates that a woman is considered stateless, and therefore, unfit to own land, which by its very nature is fixed.

\section{Health seeking behaviour}

Another risk factor for HIV/AIDS transmission among women in Cameroon is health seeking behaviour. In a study of women health seeking behaviour by Ndumbe [23] in five provinces in Cameroon respondents revealed that their husbands took most of the decision on when to seek health services. Husbands were cited by most of hospitalized $[55 \%]$ and non-hospitalized respondents as responsible for the payment of health bills for the family [24]. Furthermore, some of those interviewed revealed that the degree of women access to health care depends on the nature of the disease.

Findings from a cohort study by Mboppi et al [32] showed that HIV was twice higher in women with positive vs. negative syphilis serology. The study which compared pregnant women with a population of women with a high incidence of heterosexually acquired HIV in Yaoundé, identified by positive syphilis serology, revealed that the prevalence of HIV infection has remained high and stable in women with past or current syphilis, over the same period and that genital ulcer disease increases male-to-female sexual transmission of HIV [32]. Results of the study confirmed that women who were seropositive for syphilis in Cameroon had higher risk for HIV infection.

\section{Violence against women}

Violence against women has also been identified as one of the factors that place women in Cameroon at a great risk of contracting HIV/AIDS. Results from the 2004 CDHS suggested that one in two women [53\%] experienced physical violence with the most frequent perpetrators being husbands[28]. Violence against women in Cameroon occurs at three levels; state, community and personal and includes rape, battering and trafficking of women. A Report by the Committee against Torture and Violence against women in Cameroon stated that at the community and personal levels factors such as traditions, cultural values and poverty are seen as accounting for this practice [33]. While at the national level the absence of any laws that specifically criminalize domestic violence or marital rape and acceptance of the principle that a man has "disciplinary rights" over his wife by state judges' fuels this practice in Cameroon [33]. According to the study, violence is not reported because women are afraid of being shunned by the community and also due to the economic dependence of domestic violence victims on their aggressors and this discourages the report of this practice [33].

\section{Female Genital Mutilation}

A study of the Laws and Policies Affecting the Reproductive Lives of seven Francophone African countries found that in Cameroon, Female Genital Mutilation (FGM) is still practiced in some regions of the country, especially in North, Southwest, and Northeast provinces [31].

The WHO and UNFPA, reports that up to $20 \%$ of all women in Cameroon undergo the practice of FGM. In the three provinces where FGM is practiced, it affects 100 percent of Muslim girls and 63 percent of Christian girls' according to a Report by the Committee against Torture on violence against women in Cameroon [33]. This rite is usually practiced at the age of puberty, although in 
some cases it is performed on young girls between 6-8 years old and is generally part of a rite of passage preparing girls for womanhood and marriage [33]. A woman who is not mutilated is regarded as a pariah and is rejected by society and as such in many cases women are either in support of the continuation of female genital mutilation or regard it as a misfortune to which they have to inevitably succumb [33]. The study further reveals that at present, Cameroon has no policies that address this subject and there is no systematic treatment or counselling of victims of the practice [33]. Another report on Women's Reproductive Rights in Cameroon asserts that FGM is performed without anaesthesia under non-hygienic conditions by untrained practitioners, sometimes leading to fatal or serious health complications [34].

\section{Age mixing}

Another important factor for HIV/AIDS transmission among women is age mixing. A study by Meekersa et al, [16] based on focus-group discussion examined current types of premarital sexual relationships among urban youths, the motivations for both males and females engagement in such relationship. They indicated that many young women had boyfriends and most often older wealthy men whom they did not intend to marry known as "sugar daddies" [16]. More detailed inquiries revealed that adolescent girls frequently entered into such relationships in order to achieve specific goals, for example; to acquire financial support in order to maintain an expensive life style, which they cannot otherwise afford owing to their limited pocket allowance [16]. Studies that have explored gender differentials in young people's relationships with "sugar daddies" and "sugar mommies" have consistently indicated gender gap in motives and expectations from these relationships. A study by Mburano [16], explained that while young boys are also concerned with this practice, girls are more vulnerable than the latter. In Cameroon, $40 \%$ of female adolescents reported that they had been forced or tricked into sex [15]

\section{Cameroon current policy on gender and HIV/AIDS}

According to the Plan Strategique National de Lutte Contre le SIDA, Cameroon policy on gender and HIV/AIDS involves the following aspects: prevent sexual transmission of HIV/AIDS by promoting programs among high risk groups such as awareness programs for women, provision of female condoms and microbicide, conduct training among traditional midwives, leaders of initiation societies, and traditional leaders on prevention of STDs and AIDS and develop systematic STD testing for pregnant women consulting in hospitals [28].
Furthermore, Cameroon policy also involves well designed national guidelines on the prevention of vertical transmission from mother-to-child through the creation of centres for voluntary testing in all the health care structures for women; provision of nevirapine to at least $60 \%$ of seropositive pregnant women and follow-up with mother and child after delivery, create reinsertion centres for pregnant adolescents women, integrate counselling for women living with HIV/AIDS and family control in all health centres, increase the knowledge of seropositive women on contraception methods by at least $20 \%$ each year [28]. On the legal aspect it involves identifying legal and ethical problems linked with HIV/AIDS status in Cameroon and conduct action to prevent child prostitution.

\section{Discussion}

This review has found that in Cameroon more women are infected with HIV/AIDS than men [28]. In addition, the review found that the feminization of poverty, health seeking behaviour, violence against women, FGM and age mixing were gender related risk factors for HIV/AIDS transmission in Cameroon [21,23,34,32,17]. High prevalence of HIV/AIDS among women and gender risks factors identified in this review have also been reported in other parts of SSA [43, 44, 46, 48]. Furthermore, the review also found that at the policy level, the government has drawn up plans to reduce the high prevalence of HIV/AIDS among women, for example, awareness programs and provision of female condoms and microbicide [28].

In both urban and rural areas, 8.4 percent and 4.8 percent of women, as compared to 4.7 percent and 2.8 percent of men were HIV/AIDS positive [27]. Urbanization is associated with higher levels of HIV infection [27]. Evidence suggests that urban residents, and particularly urban youth, tend to show higher levels of awareness of HIV/AIDS and ways of avoiding HIV infection than rural residents [16], but are more prone to risky sexual behaviour. Studies in Cameroon have shown that poor single mothers, spinsters or unemployed migrants from rural to urban areas, uneducated girls, and petit traders involved in bar business engage in sexual relations to meet with up with their basic economic needs and take care of their children [25]. For this group, assistance with economic survival; (fees to stay in school, living expenses, food and cloth are their motivations for entering high risky and unprotected sexual relationship [14, 25]. Recent studies using UNAIDS data have shown that, in many countries of SSA, HIV/AIDS is disproportionately an urban phenomenon [35]. According to UNAIDS, in 21 countries in SSA the HIV prevalence rate among women attending antenatal clinics in urban areas exceeds that of 
pregnant women in predominantly rural districts [36].

On the other hand results from this review have also shown that in Cameroon women with secondary and higher education had a higher HIV/AIDS prevalence (8.2 percent) when compared to their counter part with primary and secondary education that had 3.4 percent and 4.2 percent respectively [27]. However, in a study on the association between educational attainment and risk of HIV among women in Yaoundé it was found that those with more schooling had lower risks of HIV/AIDS infection [37]. This shows that there is no direct relation between education and HIV/AIDS prevalence. For instance, a study carried out in Karonga District, Malawi in 19871989 showed higher risk of HIV/AIDS infection among better educated in comparison with those with lower education [38].

It has been argued that more educated individuals change partners more rapidly, in part because they are more mobile and because they have greater control over their own sexual behaviour [38], are sexually active for a long period of time because of delayed marriage and on this ground most likely to be at risk of contracting HIV/AIDS [38]. With the later stages of the HIV/AIDS epidemic, when education campaigns have begun and information is available about prevention methods, the educated are more likely to change their behaviour and this mitigates against socio-economic factors putting them at greater risk of infection [38]. Evidence and theory suggest that educated people should be more likely to adopt safe sexual practices in response to health promotion and as such are able to increase selfefficacy in general [39], negotiate safe sex with a partner [39] and are more likely to seek treatment for other sexually transmitted diseases which would otherwise increase their chances of becoming infected with HIV [39].

Studies conducted in Africa in the mid 1990s have reported higher HIV prevalence among the more educated; because of the absence of HIV/AIDS education campaigns, whereas later studies were more likely to find the opposite [40]. The clearest evidence comes from a cross-sectional survey in the rural areas of Masaka district, Uganda [38]. In that survey, the prevalence of HIV in the adult population declined from its peak of 14 percent in the early 1990s to around 5 percent at the end of that decade largely due to a strong prevention campaign [38].

In Cameroon, the hypothesis that at a later stage of the epidemic educated people is likely to change their behaviour because of the availability of health promotion information may not be applicable. This might be the case because the 2004 CDHS found that 42 percent of women with higher education as compared to 13 percent and 5 percent of women with primary and no education respectively were aware of the two important ways or preventing HIV/AIDS (using condoms and having sex only with one faithful uninfected partner as means of protection against HIV infection), while rejecting the two most common local misconceptions about AIDS transmission or prevention misconceptions (mosquitoes and supernatural means [27]. This indicates that despite the fact that a comparatively larger proportion of women with higher education as compared to those with secondary or primary education were aware of HIV/AIDS prevention methods this group nonetheless had the highest prevalence rate. It could be that the socio-economic position, opportunities for travel, delay at first marriage and other factors that accompany education may increase behaviours leading to a higher risk of HIV infection [38].

Another important finding of this study was that in Cameroon, the feminization of poverty placed women at an increased risk of contracting the HIV/AIDS virus. The intersection of poverty (or economic inequality) and gender vulnerability to HIV results in poor women being more likely to exchange sex for money or favours and less likely to negotiate protection in a relationship that they might perceive to be risky [34]. Women's economic dependence increases their vulnerability to HIV. In addition, unequal gender relations and access to economic resources result in women having greater exposure to high-risk survival practices.

Women constitute 52 percent of the population of Cameroon and play a very crucial role in the development of society [20]. Unfortunately, they find themselves in a subordinate position inherent from traditional and state institutions [20]. Poverty and inequality at the national level means that women have limited opportunities [40]. It is not at all surprising in these circumstances that the poor adopt behaviours, which expose them to HIV infection. Even if the poor understood what they are being urged to do, it is rarely the case that they have either the incentive or the resources to adopt the recommended behaviours [41]. A study on poverty and sexual risk behaviour among young people in Bamenda found that young people whose fathers were unemployed and those who lived in poor households were more likely to have multiple sexual partners or to have had casual sexual relations than others [41].

Violence against women was another risk factor for gender differences in HIV/AIDS transmission in Cameroon [27, 33]. There is growing evidence linking the epidemics of HIV and violence against women [42]. Violence against women is deeply rooted in patriarchal stereotypes and gender roles that often result in the abuse of women being 'normalised' or legitimised within domestic relationships. Violence against women 
has been linked to numerous negative physical and mental health outcomes [43]. In the context of HIV/AIDS infection and other STDs, forced domestic sexual compliance is a major barrier to women being able to decide if, when and how sexual intercourse takes place. It infringes their right to sexual autonomy and makes them extremely vulnerable to HIV infection. [44].

Findings from a Voluntary Counselling and Testing Clinic in Dar es Salaam, Tanzania confirm a strong association between prior history of violence and women's HIV status [45]. Women infected with HIV were significantly more likely to have had a physically violent partner in their lifetime and to have experienced physical violence, sexual violence, or both with their current partner [45]. A study in Soweto, South Africa categorized violence against women into intimate partner violence, male control in relationships, child sexual assault, forced first intercourse, and adult sexual assault by a non-partner [46]. The study concluded that the experience of being physically and sexually assaulted by a male intimate partner was associated with increased risk of HIV infection, while child sexual assault, forced first intercourse, and adult sexual assault by non-partners showed no independent effect on HIV serostatus [46]. In Cameroon, most frequent perpetrators of physical violence against women were their husbands [29]. Determining whether this kind of violence has a direct relationship with the risk of HIV/AIDS infection among women in Cameroon, as in the case of Soweto, will be important for effective intervention.

This review also found that gender differences in decision -making also affects women's access to health facilities [23]. Studies in Cameroon show that women's access to health care depended on the nature of the disease as well as the husband (who took decisions because he bears the financial costs of treatment). A study conducted in Tanzania found that while men made independent decisions to seek voluntary counselling and testing services, women felt obliged to discuss testing with their partners before accessing the service thereby creating a potential barrier to accessing services [45]. Although the study in Cameroon did not specifically mention what type of diseases influence women's access to health [23], research in SSA show that a gender paradox exists in the stigmatization of STDS and HIV/AIDS [42], while it is almost universally acknowledged and accepted that men are much more likely to have had multiple sex partners, society's disapproval somehow ends up on the heads of women rather than men as women may be more affected by stigma and discrimination than men because of social norms concerning acceptable sexual behaviour in women. [43]. Stigma associated with HIV/AIDS is a major factor preventing many women from accessing health services. Faced with stigmatization women are more likely to avoid health services for the screening and treatment of STD's. Yet strong evidence supports several biological mechanisms through which STIs facilitate HIV transmission by increasing both HIV infectiousness and HIV susceptibility [42]. For instance, the high prevalence of HIV infection in pregnant women in Yaoundé has been partly attributed to seropositivity for syphilis. This demonstrates that syphilis is a biological cofounder to HIV/AIDS- as a genital ulcer disease; it increases male-to-female sexual transmission of HIV [32]. This finding is also consistent with the observations reported in 1988 in Bangui (Central African Republic) showing a strong association between seropositivity for syphilis and seropositivity for HIV among individuals with genital ulcer disease [32]. In the rural village of Mwanza, Tanzania it was found that STDS intervention reduced the incidence of HIV/AIDS within a two-year period by $40 \%$ [47]

It has also been found that in some parts of Cameroon, women undergo FGM, which have devastating health consequences. FGM predisposes women to HIV infection in many ways: increased need for blood transfusions due to haemorrhage either when the procedure is performed, at childbirth, or a result of vaginal tearing during defibulation and intercourse [48]. In addition, it makes penetration or intercourse difficult, often resulting in tissue damage. The use of same equipment for many girls increases the chances for transmission of HIV/AIDS through contact with contaminated blood. A study conducted on 7350 young girls less than 16 years old in Dar es Salaam revealed that $97 \%$ of the time, the same equipment could be used on 15-20 girls. The conclusion of that study was that the use of the same equipment facilitated HIV/AIDS/STD transmission [48].

Age mixing was another important risk factor for gender differentials in HIV/AIDS prevalence in Cameroon [16]. Young women are at a greater risk of HIV/AIDS infection. Studies that have explored gender differentials in young people's relationships with sugar daddies and sugar mummies have consistently indicated a gender gap in motives and expectations from this relationship [49]. It is suggested that more girls are involved in vulnerable relationships with sugar daddies than young boys with sugar mummies [49].

Economic vulnerability, unequal economic opportunities and peer pressure among young girls account for gender differentials in this high risk practice [50]. Age mixing in sexual relationships inevitably brings the girls into contact with the high-risk segments of the population regarding STI and HIV/AIDS. This is so because sexual activity, like other decisions negotiated between a partner, is not just an individual attribute but a behaviour negotiated within a wider social, cultural, and 
economic context that has to do with power differentials between them [50].

Large differentials can place the weaker partner at great risk, because he or she has relatively less power to control sexual encounters [51]. With the case of "sugar daddies" age and economic asymmetries are seen as distinct types of power differentials within sexual partnerships. In Cameroon, relationships between young and old people are favourable to the submission of the former to the latter. Studies on urban youths in Yaoundé show that female in situations of transactional sex girls are less able to decide the timing and conditions of sex, thus experience a higher risk of becoming pregnant and contracting STI's, including HIV/AIDS [51]. One of the few studies linking age gap differentials with HIV infection conducted in rural eastern Zimbabwe concluded that sexual relationships with older men put young people (particularly girls) at high risk of HIV infection. The risk of HIV infection among 17-24-year-old women increased with the cumulative number of partners and number of years by which women were younger than their most recent partner [52].

\section{Policy implications}

The findings described above suggest that sociocultural and economic factors partly explain women's vulnerability to HIV/AIDS transmission in Cameroon $[16,20,23,31,33]$. Hence it is important that policies that seek to address women vulnerability to HIV/AIDS take into account these factors. At the policy level, the government of Cameroon has recognized women as a high risk group and put in place plans and policies to reduce the high HIV/AIDS prevalence among them. In the current policy, several goals such as, awareness programs for women, provision of female condoms and microbicide, have been put forward [28]. These goals should be achieved through a multi-sectoral and decentralised approach.

At the political and legal level, the lack of political will and the passiveness of the authority in their duty, blatant embezzlement of HIV/AIDS funds and the reliance on a top- down approach have all marred the efforts in the fight against HIV/AIDS in Cameroon. Poor coordination between the over 48 enterprises and 6000 NGOs working alongside the government in the fight against AIDS means that efforts are either duplicated or there is little sharing of information to learn from and replicate successful interventions [53]. On the legal front, the plan to identify legal and ethical problems linked to HIV/AIDS status in Cameroon and conduct action to prevent child prostitution and violence against women have not been implemented and discrimination against women in employment, certain harmful cultural practices like FGM continue to be part of women's everyday life. Therefore, efforts should be made to enforce or to promote the legal status of women. This is crucial for containing the feminization of the HIV/AIDS epidemic and mitigating its impact. On the other hand women empowerment through economic programs should be promoted in order to enable them change to a better socioeconomic status. In addition certain cultural practices such as FGM that put women at risk of HIV/AIDS infection need to be abolished and their practice criminalized. Women should be able to take part or have a share in both resource and power allocation as well as have the legal right to inherit property. This will lead to a level of control where they are able to direct or influence events so that their interests are protected and they are empowered at all levels.

There is also an urgent need to decentralize current HIV/AIDS program, which so far have been limited to few cities to all the country and especially rural areas. The key to achieve success in redressing the high prevalence of HIV/AIDS will be through a bottom-up approach. In Cameroon, the traditional top-down approach has failed several times over the years. Community participation should be reinforced through already existing traditional structures like development associations, social gatherings, women organizations and religious bodies. The government should give priority to women's organizations that often complain of limited or no funding. However, while women should remain the focus of HIV/AIDS, there is a dire need to include men. The current Cameroon's Plan Strategique National de Lutte Contre le SIDA, does not indicate as one of its strategy the inclusion of men in tackling the feminization of HIV/AIDS. Women cannot achieve gender equality, sexual and reproductive health without the cooperation and participation of men. It is men who usually decide on the number and variety of sexual relationships, timing and frequency of sexual activity through coercion or violence [54]. The 'feminization' of the AIDS pandemic in Cameroon is a sad reminder that in many circumstances women do not have the power to protect their own health. Men - as community, political or religious leaders - often control access to reproductive health information and services, economic resources and thus often wield enormous power over many aspects of women's lives [55]. Effective programs that recognize and increase men's comfort with seeing themselves as responsible, caring, and non-violent partners will be important to bringing about long lasting gender equality in Cameroon. One of the root causes of the spread of the HIV/AIDS virus is poverty. More programs should be organized that focus on poverty alleviation among women. A multisectoral approach that incorporates the ministry of Economy and Finance, Agriculture, 
Labour and Employment and Women's Affairs could be a useful way to combat the epidemic.

The government of Cameroon needs a sustainable commitment in addressing gender related discrimination that fuels the HIV/AIDS epidemic in Cameroon. It is only with a strong political will that legislative reforms could be translated into proactive actions that could reverse the trends of the epidemic among women. If these issues are not taken into account, it is most likely that, again Cameroon will propose another strategic plan that will be so good on paper but completely fails to address specific needs of women.

\section{Limitations}

The significant constraint faced in this review was the paucity of scientific studies on Francophone Africa in general and Cameroon in particular on gender and HIV/AIDS. In addition there were very few materials addressing the subject of the feminization of HIV/AIDS in sub-Saharan African countries.

\section{Conclusion}

This literature review examined gender differentials in HIV/AIDS in Cameroon and to which extent gender was taken into account in the country's current policy on HIV/AIDS. Results showed that in Cameroon women were at increased risk of being infected with HIV/AIDS compared to men and that apart from physiological vulnerability, socio-cultural as well as economic factors accounted for those differences. The review also found that at the policy level, the government has drawn up plans to reduce the high prevalence of HIV/AIDS among women. However, although Cameroon's current policy acknowledges the need to tackle gender differentials in HIV/AIDS transmission; little has been done at the level of implementation. Thus, the implementation of the current policy needs to be more effective with emphasis on a multisectorial approach in order to curb the current trend of the feminization of HIV/AIDS in Cameroon. Furthermore, the Cameroon Government should make a political commitment to sustain the implementation of policies aimed at improving women's health and well being.

\section{References}

1. UNAIDS Report. Report on the Global Aids Epidemic. Geneva 2006: pp. 1-21 http://data.unaids.org/pub/GlobalReport/2 006/2006 GR-ExecutiveSummary en.pdf (Assessed 10 March 2006).

2. UNAIDS/WHO Joint United Nations Program on HIV/AIDS. Geneva 2005; pp $2-10$
http://www.unaids.org/epi2005/doc/EPIup date2005 pdf en/epi-update2005 en.pdf

(Assessed 14 December 2005).

3. World Wide HIV and AIDS Epidemic Statistics. Sussex 2006; pp 1-13 http://www.avert.org/worlstatinfo.htm (Assessed 18 February 2006).

4. Holler Africa. The Feminization of HIV/AIDS Johannesburg 2004; pp 15.http://www.hollerafrica.com/showArticl e.php?artId=74\&catId=3 (Assessed 18 February 2006).

5. Commission on HIV/AIDS and Governance in Africa. Addis Ababa 2004; pp 10-15:

http://www.uneca.org/chga/gender hiv ai ds.pdf (Assessed 15 December 2005).

6. UNIFEM. HIV/AIDS and feminism, Durban 2004; pp 1-2 http://www.awid.org/forum2002/plenaries /AIDS and Feminism.html (Assessed 14 December 2005)

7. United Nations General Assembly Special Session on HIV/AIDS. Progress Report on the Global Response to the HIV/AIDS Epidemic. Geneva 2003; pp 2345http://whqlibdoc.who.int/unaids/2003/9 291732885 (Assessed 15 December 2005)

8. Africa Region Gender Team. Putting Gender on the MAP. New York: The World Bank, 2000;pp1-28 http://www.sahims.net/batchfiles_web/03 07/The \%20Gender\%20Dimensions $\% 20$ o f\%20HIVAIDS.pdf (Assessed 14 June 2006)

9. Collins J, Rau B. AIDS in the context of development. Paper No 4 UNRISD Programme of Social Policy and Development, Geneva: The United Nations Research Institute for Social Development, 2004; pp 1-76".

10. Canadian HIV/AIDS Legal Network. Using Rights and the Law to Reduce Women's Vulnerability to HIV/AIDS, Durban 2000; pp 1-10 http://www.aidslaw.ca/durban2000/wome nfinal.pdf (Assessed 20 June 2006)

11. Piot P, Bartos M, Ghys PD, Walker N and Schwartländer B. The global impact of HIV/AIDS. Nature 2001; 410: 968-973

12. Rao GG. Approaches to empowering women in the HIV/AIDS pandemic, Namibia 2000: pp. 14-22 http://www.un.org/womenwatch/daw/csw/ hivaids/Gupta.html (Assessed 15 May 2006).

13. Togni L. AIDS in South Africa and on the African continent. Pretoria: Kagiso Publishers; 1997. pp 10-15 
14. University of Minnesota. Committee on the Elimination of Discrimination Against Women, Yaounde 2000; pp 1-4 http://www1.umn.edu/humanrts/cedaw/ca meroon2000.html (Assessed 15 December 2005)

15. Jean-Robert RM. Statut de la Femme et Utilisation des Condoms au Cameroun. African Journal of Reproductive Health 2003; 7:74-88

16. Meekers D and Calves AE 'Main' girlfriends, girlfriends, marriage, and money: the social context of HIV risk behaviour in sub-Saharan Africa. Health Transit Review. 1997; 7: S361-375.

17. Rhodes T, Cusick L. Love and intimacy in relationship risk management: HIV positive people and their sexual partners. Sociology of Health and Illness. 2000: 22: 44-48

18. Susser I, Stein Z. Culture, sexuality and women's agency in the prevention of HIV/AIDS in Southern Africa. American Journal of Public Health. 2000; 90:10421048.

19. The World Fact Book. Cameroon. 2005. pp $1-10$ http://cia.classifieds1000.com/print/Camer oon.html (Assessed 14 June 2006).

20. Fonjong L. Fostering women's participation in development through nongovernmental efforts in Cameroon. Geography Journal. 2001; 167:223-234

21. Memfih M. Assessing the socio-economic effects of HIV/AIDS at the level of households in Cameroon. A Paper Submitted for Presentation at the IAEN Conference on the AIDS-Development Nexus, Cape Town 2005; pp 1-24 http://www.iaen.org/files.cgi/14606 Socio economicEffectsHouseholdsCameroon.pd

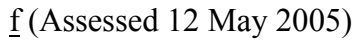

22. United Nations Development World Report. Country Sheet, Cameroon 2005, $\mathrm{pp}$ 1-3

http://hdr.undp.org/statistics/data/countries .cfm? $=$ CMR (Assessed 15 2006).

23. Ndumbe P. Women and Access to Health Services in Cameroon. Studies and Works from Social Policy Research Network No 3, West and Central Africa, Dakar 1999; pp $5-7$

http://idrinfo.idrc.ca/archive/corpdocs/112

818/Cameroon.htm (Assessed 15 April2006)

24. World Health Organization. Summary Country Profile on HIV/AIDS Treatment Scale up, Geneva 2005; pp 1-2 http://www.who.int/3by5/support/june200 5 cmr.pdf (Assessed 13 December 2005).
25. Nyambi P, Zekeng L, Kenfack H, Tongo M, Nanfack A, Nkombe I, Ndonko F, Shang J, Burda S, Mbah H, Agyingi L, Zhong P, Nadas A, Zolla-Pazner S, Marmor M. HIV Infection in Rural Villages of Cameroon. Journal of Acquired Immunodeficiency Syndrome. 2002: 31; 506-513.

26. UNAIDS: Annex 2: HIV and AIDS estimates and data Geneva 2005; pp 506507.

http://www.unaids.org/en/HIV_data/2006

GlobalReport/default.asp (Assessed 20 December 2005).

27. Cameroon Demographic and Health Survey. Yaounde 2004; pp 5-25. http://www.measuredhs.com/pubs/pdf/SR 107/SR107.pdf (Assessed 15 September 2005)

28. Plan Strategique National de Lutte Contre le SIDA, Third Draft 2000-2005 Yaounde 2000; pp 1-12 URL http://www.hsph.harvard.edu/hai/africano w/pdfs/cameroon.pdf (Assessed 03 May 2006).

29. UNAIDS/WHO Epidemiological Fact sheet on HIV/AIDS. Yaounde 2004; pp 116

http://www.who.int/GlobalAtlas/predefine dReports/EFS2004/EFS PDFs/EFS2004

CM.pdf (Assessed 17 June 2006)

30. Mbopi Kéou FX, Mpoudi-Ngollé E, Nkengasong J, Zekeng L, Mbanya D, Affana G, Mauclere P, Monnylobe M, Tapko JB, Ndumbe P, Salla R, Kaptue L, Belec L. Trends of AIDS Epidemic in Cameroon, 1986 Through 1995. Journal of Acquired Immune Deficiency Syndrome and Human Retroviral. 1998; 18:89-91

31. Center for Reproductive Rights. Women of the World: Laws and Policies Affecting Their Reproductive Lives, New York 2000; pp 66-89 http://www.crlp.org/pub bo wowfr.html\# pdf (Assessed 17 April 2006)

32. Mbopi Keou FX, Mbu R, Mauclere P, Andela A, Tetanye E, Leke R, Chaouat G, Barre-Sinoussi F, Martin P, Belec L. Antenatal HIV prevalence in Yaounde, Cameroon. International Journal of Sexual Transmitted Diseases and AIDS 1998; 9:400- 402

33. Violence against Women in Cameroon: A Report to the Committee against Torture. Yaounde 2003; pp 3-38 http://www.omct.org/pdf/vaw/publications /2003/eng 2003 03 cameroon.pdf (Assessed 15 April 2006).

34. The Center for Reproductive Law and Policy. Women's Reproductive Rights in 
Cameroon: A Shadow Report, New York 1999; pp 1-21 http://www.crlp.org/pdf/sr cam 1199 eng .pdf (Assessed 15 March 2006)

35. Buvé A, Bishikwabo-Nsarhaza $\mathrm{K}$ and Mutangadura G. The spread and effect of HIV-1 infection in sub-Saharan Africa. Lancet. 2002; 359: 2011-2017.

36. UNAIDS. Report on the Global AIDS Epidemic. Geneva 2006; pp 5-28 http://data.unaids.org/pub/GlobalReport/2 006/2006 GR-ExecutiveSummary en.pdf (Assesed 15 May 2006).

37. Glynn JR, Carae LM, Buve A, Anagonou S, Zekeng L, Kahind M, Musonda R, Study Group on Heterogeneity of HIV Epidemic in African Cities. Does increased general schooling protect against HIV infection? A study in four African cities. Tropical Medicine and International Health. 2004; 9:4-14.

38. Glynn JR, Ponnighaus J, Crampin AC, Sibande F, Sichali L, Nkhosa P, Broadbent P, Fine PE. The development of the HIV epidemic in Karonga District, Malawi. AIDS. 2001; 15: 2025-2029.

39. Jukes M and Desai K. A report prepared for the UNESCO Global Monitoring Report 2005 http://portal.unesco.org/education/en/file download.php/6c5eeae6d430e16f1fc891d 55e026769Jukes +M 3.doc (Assessed 11 January 2006).

40. Desmond C. Poverty and HIV/AIDS in Sub-Saharan Africa. Issues Paper No. 27 pp

UNDPhttp://www.undp.org/hiv/publicatio ns/issues/english/issue27e.html (Assessed 17 June 2006).

41. Rwenge M. Poverty and Sexual Risk Behavior among Young People in Bamenda, Cameroon. Etude Population Afrique. 2003; 18; 91-104

42. Maman S, Campbell J, Sweat MD and Gielen AC. The intersections of HIV and violence: directions for future research and interventions. Social Science and Medicine. 2000; 50:459-478.

43. Jacobs T. Domestic Violence and HIV/AIDS: An area for urgent intervention, Cape Town 2003; pp 1-8 ppwww.preventgbvafrica.org/Downloads/ hivaids.DV.tanyajacobs.SA.pdf (Assessed 15 April 2006)

44. Weiss E. and Rao GG. Bridging the Gap: Addressing Gender and Sexuality in HIV Prevention. Washington DC 1999: pp 1-7

45. Maman S, Mbwambo JK, Hogan NM, Kilonzo GP, Campbell JC, Weiss E, and Sweat MD. HIV-Positive Women Report
More Lifetime Partner Violence: Findings From a Voluntary Counselling and Testing Clinic in Dar es Salaam, Tanzania. American Journal of Public Health. 2002; 92;1331-7

46. Dunkle KL, Jewkes RK, Brown HC, Gray GE, McIntryre JA, Harlow SD. Genderbased violence, relationship power, and risk of HIV infection in women attending antenatal clinics in South Africa. Lancet. 2004; 363:1415-21

47. Grosskurth H, Mosha F, Todd J, Mwijarubi E, Klokke A, Senkoro K, Mayaud P, Changalucha J, Nicoll A, kaGina $G$, et al. Impact of improved treatment of sexually transmitted diseases on HIV infection in rural Tanzania: randomised controlled trial. Lancet.1995; 346:530-6

48. Brady M. Female Genital Mutilation: Complications and Risk of HIV Transmission. AIDS Patient Care STDS. 1999; 13:709-716

49. Rwenge JR. Poverty and Sexual Risk Behaviour among Young People in Bamenda, Cameroon. Etude Population Afrique. 2003 ;18: 91-104

50. Luke N. Confronting the 'Sugar Daddy' Stereotype: Age and Economic Asymmetries and Risky Sexual Behavior in Urban Kenya. International Family Planning Perspectives. 2005; 31:6-14

51. ManLI, Kuate MY. Effects of Socioeconomic Disadvantage and Women's Status on Women's Health in Cameroon. Social Science and Medicine. 1997; 47:1023-1042

52. Gregson S, Nyamukapa CA, Garnett GP, Mason PR, Zhuwau T, Carael M, Chandiwana SK, Anderson RM. Sexual mixing patterns and sex-differentials in teenage exposure to HIV infection in rural Zimbabwe. Lancet. 2002; 359:1896-1903

53. Tanyi C. Monitoring the Implementation of the UNGASS Declaration of Commitment Country Report Cameroon, Yaounde pp 12-19. http://www.icaso.org/ungass/country\%20r eports/Cameroon\%20UNGASS\%20report \%20ENGLISH $\% 20$ FINAL.pdf

(Assessed 18 July 2006)

54. United Nations Development Program. Men and the HIV epidemic London 1999 pp 1-8

http://www.undp.org/hiv/publications/gen der/mene.htm (Assessed 15 June 2006)

55. UNFPA: Involving Men in Promoting Gender Equality and Women's Reproductive Health. New York 2006 pp 1-3 http://www.unfpa.org/gender/men.htm (Assessed 18 June 2006) 